\title{
HUMAN RESOURCES AND R\&D AT THE INSTITUTE FOR NANOMATERIALS, ADVANCED TECHNOLOGIES AND INNOVATION (TUL)
}

\begin{abstract}
Within the next few years, Europe's economic paradigm will change fundamentally. Its manufacturing base will continue to shrink, and therefore future growth and social welfare will rely increasingly on knowledge-intensive industries and services, and ever more jobs will require a higher education qualification. Human resources are a core determinant of quality in higher education and research. Universities must therefore work to enhance their human potential, both qualitatively and quantitatively, by attracting, developing and keeping talent in teaching/research careers. Excellence may only emerge from a favourable professional environment based in particular on open, transparent and competitive procedures. Research and development (R\&D) has proven to be a crucial factor in shifting the world's technological frontiers, while at the same time facilitating new technological and scientific innovations. This paper will focus on R\&D at the Institute for Nanomaterials, Advanced Technologies and Innovation at the Technical University of Liberec, Czech Republic. After a description of a literary search in the introduction, the specific real situation at this institute is mentioned, i.e. the number of submitted and solved national and international projects, statistics on research and development sources, and of course human resources at the institute. In the conclusion, the reader will be able to get a picture of how to increase the institute competitiveness in international collaboration.
\end{abstract}

Keywords: research and development, university, human resources, R\&D project, environment

\section{Introduction}

According to the Frascati definition of research, research and development (R\&D) comprise creative and systematic work undertaken in order to increase the stock of knowledge - including knowledge of humankind, culture and society - and to devise new applications of available knowledge. As we can see over the last few decades, there has been a tremendous increase in the international flow of knowledge and exchange of practice in such fields as natural or social and economic sciences, which has resulted in bringing R\&D activities to a completely different level, and they are now considered as one of the major factors in world economic growth. As specified by modern scientific literature, the role of R\&D has become a crucial factor in shifting the world's technological frontiers and promoting new technological and scientific developments, whereby contributing to an increase in economic growth and technological advancement at the national level.

\footnotetext{
${ }^{1}$ Technical University of Liberec, Studentská 2, Liberec 461 17, Czech Republic, phone +420 777863422 , email: pavla.svermova@tul.cz

*Corresponding authors: alena.kabova@tul.cz, olha.starostina@tul.cz,marketa.pankova@tul.cz
} 
The influence of advanced technological processes and $R \& D$ is seen in various economic sectors and fields through:

- providing innovative solutions to infrastructure systems (transportation, energetics, telecommunications, environment protection, etc),

- increasing the output of the industrial enterprises (raw materials, motors, electricity, agriculture, fisheries, etc) and services,

- improving the quality of consumers' products and services (in the food sector, housing, environment), thereby contributing to their well-being.

There is no doubt that technological innovations and $R \& D$ play a leading role in initiating, enhancing and sustaining economic growth in the modern world [1-4].

It is also believed that the present state of $R \& D$ covering all three levels:

- business R\&D,

- foreign $R \& D$,

- $\quad$ public R\&D

and involvement of state and private institutions will further boost and ensure durable economic growth by introducing new innovations and applying new technological methods, and ultimately driving productivity to a higher level $[5,6]$.

Historically, this process began during the initial stages of the industrial revolution in selected countries, where scientific activities focussed on such problems and tasks as increasing productivity, bringing the development of materials to a new level, improving the quality of life, as well as addressing environmental, human health and sanitation issues, etc. The process still continues and intensifies. Using the existing scientific achievements and technological solutions and enriching them with the new trends and knowledge through additional studies and experiments led to new crucial discoveries that significantly contributed to the economic growth and wealth of industrial countries.

Universities also play an important role in this process by boosting scientific innovation and technological progresses in various different fields of the economy and production. However, the most beneficial for this process is conjugation and collaboration between universities and state/private institutions as well as industrial enterprises, which allows new discoveries and achievements to be shifted to the application phase and contribute to the economic growth and prosperity of the involved countries. Human resource management (HRM) in its turn is a strategic and coherent approach to the management of an organisation's most valued assets - the people working there who individually and collectively contribute to the achievement of the objectives of the business [7]. Specific HRM services have been established and developed during the last decade. Universities as knowledge-based organisations have a strong focus on the quality of their academic staff, as they are responsible for teaching and research. Another important prerequisite to a successful university are their services, which highly depend on the quality of the administration and management. The quality of management and academia will also depend on the quality of HRM and functions [8].

\section{Theoretical framework - Research \& Development}

Currently, the priority for research organisations is to focus their implemented research, development and innovation $(\mathrm{R} \& \mathrm{D} \& \mathrm{I})$ on the application sphere, or to combine their know-how with that of private industrial enterprises. This not only ensures effective R\&D\&I activities with a specific impact, but also leads to improved human work. Through 
collaborations, employees from research organisations and industry will exchange and strengthen their existing knowledge and skills, while at the sample time ensuring their development. Of course, these steps are not only performed at a national level; on the contrary, international overspill is also desirable. From the point of view of the given country, there is undoubtedly a higher rate of performance with a positive impact on the economy and a better implementation of new technologies. If R\&D\&I is performed hand in hand with practice, then implementation is always easier for both parties involved. Part of every activity should be a clear vision, or a definition of the expected objectives. In the field of R\&D\&I, this trivial rule can be quite demanding, but through the interconnection of research organisations and the application sphere, $R \& D$ may become a systematic activity with the assumption of success. R\&D in the field of private enterprise may result in new goods and services, higher quality of production, higher productivity, lower prices of consumer products, new production processes and sources of economic growth at the macroeconomic level. Studies performed in many developed countries (especially the US and the EU) highlight the fact that the key pillars of R\&D\&I leading to a country's long-term prosperity include:

- economic growth of the country,

- $\quad$ work productivity,

- social return.

A country's domestic and foreign productivity grows in proportion to governmental and private investment in R\&D\&I. Therefore, sufficient funding has a positive impact not only on the country directly affected, but also on others [9-11].

The triple helix of university-industry-government interactions has been the subject of not only economic but also social research in the last few decades [12-14]. The role of universities is crucial in performing institutional research, which results in technological discoveries based on new knowledge or practices. Another, newer role of universities is to create facilities for enterprises that are interested in basic research and basic technological projects, as they usually have sufficient equipment, quality human resources and the necessary know-how. It is now quite desirable for every university to support collaboration in the broadest possible sense and the transfer of current and future knowledge and experience into practice. In this respect, universities operate based on an interactive rather than linear model of innovation. In today's dynamic times, the application sphere is approaching the academic model with its proactive approach to R\&D\&I. Great emphasis is placed on increasing the technological level and creating innovative products. Activities of industrial enterprises also include professional training and knowledge sharing. The role of government is also beginning to change. In addition to its traditional regulatory approach, it often acts as a public entrepreneur and venture capital investor when setting rules [15-17].

The current development of the situation is considered the second academic revolution, because intellectual capital is considered as important as financial. Both of these components are a platform for economic growth. The above-mentioned triple helix and its function is the main driver leading to this change through innovation and subsequent development of new products. Originally, the main role of universities was to provide pedagogical activity, which has been transformed over the last two decades into a combination of $R \& D \& I$ and pedagogical activity. Hence, the importance of new knowledge and technological discoveries comes to the fore. It is no exception that universities focus on the commercialisation of their results. With the development 
of a business background, the two worlds came together to achieve the same objective for society, and with the interest in fundamental discoveries with technological applications. Industry in this connection represents the place of production (it has machines, consumer goods, market knowledge, etc.). The triple helix is closed by the government as a stable source of funds ensuring the smooth running of the set processes [18-20].

The common objective is to combine changes in technology, business models, organisations and a competitive economy. The time is such that without the innovation of existing products, services or methods of distribution, it is not possible for a private enterprise to succeed on the market in the long run or perhaps expand into new markets. Scientific competence plays an important role in the innovative capacity of industry, but there is no direct path from advanced research to innovation. The time it takes for a patented invention to become a useful product is in most cases quite long (Fig. 1).

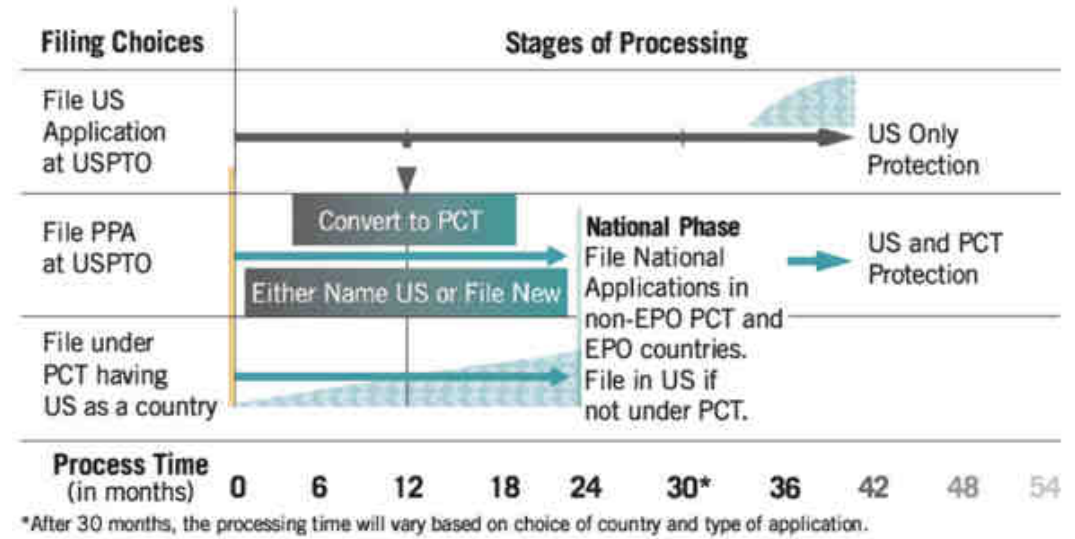

Fig. 1. Patent option timeline (LLS Health CDMO) [21]

It is quite common for most advanced industrial enterprises to invest 5-15\% of their annual income in expenditure on R\&D\&I each year. Enterprises are also aware of the fact that without collaboration with research organisations, the results are usually not so good. Not only is it possible to achieve the desired result in the form of a new product or service, a great benefit for the application sphere is also the acquisition of new competencies, and identification of new areas of knowledge that may result in future technological opportunities. Therefore, interconnection is beneficial in all respects [22].

This is a real phenomenon, as the links between universities and the application sphere and their impact on innovation processes have become the subject of analysis in a wide range of scientific communities, as well as the subject of research from the point of view of management, innovation economics, industrial organisations, sociology of science and scientific studies, and in science and technology policy. The above-mentioned transformation of universities was also due in part to other factors, including:

- a changing legislative environment,

- the growth of government initiatives in this area, which have ensured gradual partnerships between public and private research,

- increasing political pressure from universities to improve national economic competitiveness. 
The impact can be demonstrated in several ways, in particular by an increasing number of patents obtained by universities as a result of R\&D\&I. Revenues from licenses are becoming a more important source of university funding. In general, the resources invested by the application sphere into universities are growing. Academic staff are increasingly involved as researchers in so-called academic business. The trend is also to build facilities for technology transfer (science parks, incubators, supporting science offices, etc.) [23-28].

Sustainable development undoubtedly requires radical and systemic innovations. We live in a turbulent world, whose basic manifestations are long-term challenges, constant climate change, an aging population, desertification, water scarcity issues, planetary pollution and emerging shortages of key raw materials for society. Therefore, time has called on humanity to focus on new discoveries - new energy sources, environmentally-friendly processes leading to sustainable development, etc. We are in an ideal environment to take advantage of the opportunities that global innovation brings. According to the studies, innovation, especially in agriculture, industry and services, is crucial for ensuring long-term economic growth [29].

\section{Empirical investigation}

\section{Human resource management}

There is increasing emphasis by governments, organisational leaders and scholars on the importance of creativity and innovation in workplaces, to help to challenge old ways of thinking and to identify new solutions to meet current challenges. While creativity may be defined as the generation of ideas, innovation is often seen as the "stage of implementing ideas towards better procedures, practices or products". [30] It is people who are at the heart of creativity and innovation; people develop new ideas and people put them into practice. Some authors suggest that for it to be successful, HRM must be a strong system that is distinctive, consistent and based on consensus. They see a strong HRM system as one that signals to managers and employees what is expected, valued, and rewarded within the organisation [31].

The Technical University of Liberec (TUL) is well aware of the necessity to have an HRM system, which reflects the legislation in this field. The following legislation relates to public universities, among other things:

- Act 262/2006 Coll., the Labour Code - regulates relationships between employers and employees [32].

- $\quad$ Act 111/1998 Coll., the Higher Education Act - regulates freedom of research [33].

- Ethical Framework of Research - formulated basic ethical principles of behaviour and conduct of researchers, freedom of research and the related responsibilities [34].

- Act 121/2000 Coll., the Copyright Act - regulates the protection of intellectual property rights [35].

- Act 527/1990 Coll., on inventions and rationalisation proposals - regulates rights and rules relating to the discovery and implementation of inventions and rationalisation proposals [36].

- $\quad$ Act 478/1992 Coll., on utility models [37].

The above-mentioned national legislation is also reflected and specified in the following directives and regulations of TUL: 
- Rector's Directive 1/2018 Ethics Code for Employees and Students - defines freedom of research and ethical dimensions and procedures at TUL [38].

- Strategic Plan for the Scholarly, Research and other Creative Activities of TUL 2016-2020 (with annual updates) and Strategic Development Plan of TUL for 2020 with a forward view to 2030 - TUL strategic documents specifying research areas, targets, tools and resources [39].

- Rector's Directive 2/2015 Protection of Intellectual Property at TUL and Commercialisation of Scientific and Research Results - regulates copyright and industrial property rights at TUL [40].

- TUL Conditions of Employment - regulates individual and flexible working hours, home office scheme and part-time employment, employee care [41].

- Internal Wage Regulations - define basic wage levels and motivation components of staff remuneration [42].

- TUL Collective Agreement - defines relationships among trade unions, employer, employees, outlines rights and obligations [43].

In general, it may be stated that in terms of human resource management, the environment at TUL is at a high level. The interests of employees are protected by several internal regulations. Specific non-financial benefits of TUL employees, intended for motivation include:

- Using individual and flexible working hours.

- Home office and sabbatical leave.

- Career development - further education, participation at seminars/workshops/training.

- Mobility.

- TUL children's corner.

- TUL kindergarten.

- Suburban camps for school children.

- Above-standard length of holidays for researchers and technical and administrative staff.

- Accommodation at the TUL dormitory.

- Free entry to TUL sport facilities.

- Free hours in public swimming pool.

- Academic Advisory and Support Centre providing career advice.

A significant number of the above benefits are focused on reaching a balance between the work and personal life of mothers and fathers. This also helps ensure the gender balance in the framework of working conditions. Of course, in addition to the above-mentioned benefits, TUL also offers financial benefits, which are defined in more detail in the Internal Wage Regulations.

\section{R\&D and Project/Financial management at CxI TUL}

The Institute for Nanomaterials, Advanced Technologies and Innovation (CxI) is a research centre of the Technical University of Liberec. Its primary aim is to contribute to the development of the region, which is traditionally oriented towards technical industries. CxI connects the laboratories of the technical disciplines at TUL and collaboration with major players in industry. Research programmes are focused on areas of material research, competitive engineering and system integration with an emphasis on the applicability of the research and development results in practice. 
Due to the focus of $\mathrm{CxI}$ and its aim to be a top research institute, quality human resources are a key investment. The activities performed as CxI are focused on the implementation of research and development and innovation (R\&D\&I) projects with a focus on the application of results and collaboration with industry in the form of contractual research. It should also be mentioned that CxI has an average of approximately 140 regular employees.

The below graph (Fig. 2) gives a breakdown of the funding of CxI over the last six years, divided into national projects, international projects, contractual research, institutional support for the development of research organisation and other sources. National projects and contractual research are among the key sources of funding of CxI.

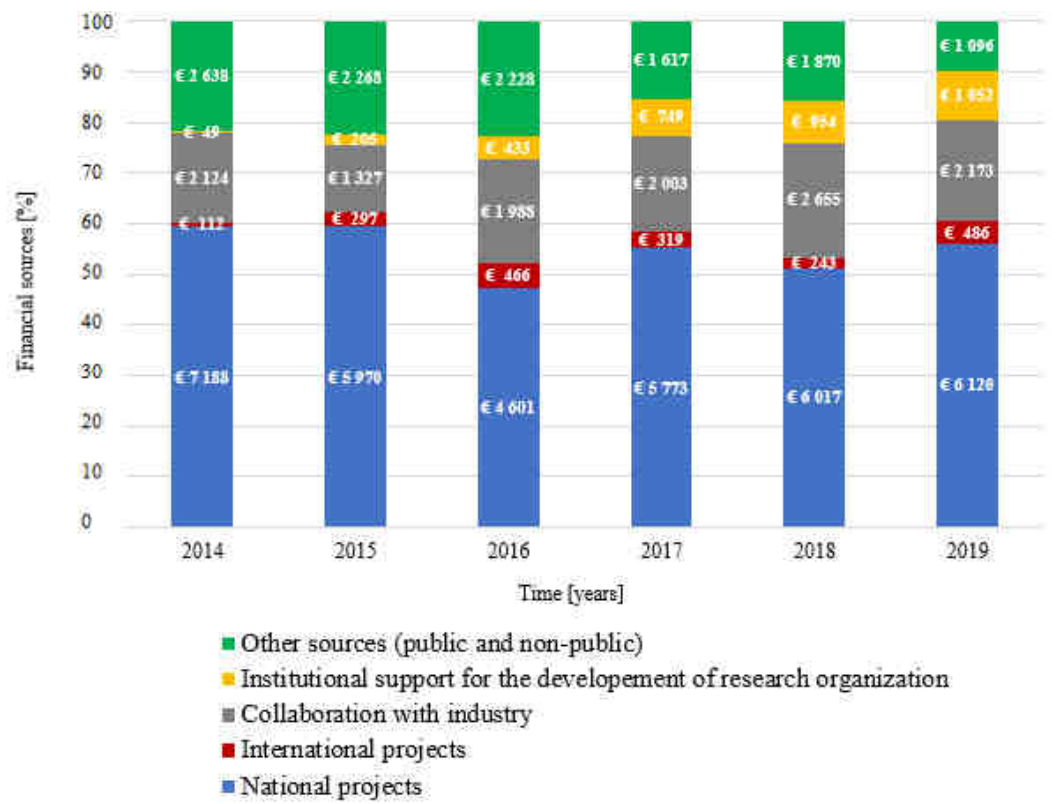

Fig. 2. Sources of funding of CxI between 2014 and 2019 (in thousands of EUR) (own elaboration). Note: Czech National Bank exchange CZK/EUR as of 31 December of the given year

From Figure 2, it is clear that CxI is very successful in the number and funding of national projects, with the amounts of resources showing a growing trend. However, revenues from international projects have been declining since 2017 and are insufficient in terms of the importance of CxI. Contractual research has a variable character and depends on the state of the Czech industry in the corresponding areas, or the ability to reorient to new industrial partners. Therefore, CxI should focus on better communication with industry and presentation of its results applicable on the market. The popularisation of R\&D\&I in the business world is already an absolutely indispensable part of the public relations of all $\mathrm{R} \& \mathrm{D}$ institutions. In this regard, CxI is working on more effective procedures in the area of technology transfer and on updating their website, which will better communicate with target groups.

In terms of international projects, there was an increase in funding until 2016, but since this year the amount of funding has declined. The situation did not improve in 2020 either, 
when the volume is only around 320 thousand EUR. As additional information, Figure 3 shows the number of ongoing international projects for the period from 2014 to 2020 .

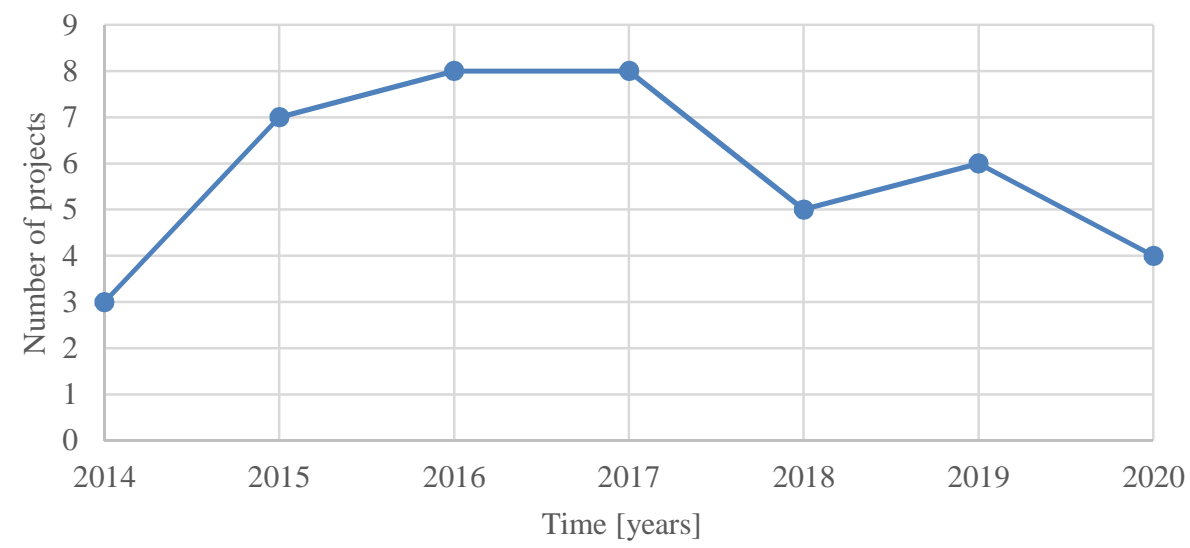

Fig. 3. Number of international projects performed at the Institute for Nanomaterials, Advanced Technologies and Innovation in the years from 2014 to 2020 (own elaboration)

Since the establishment of CxI, its priority has been to establish international collaboration across all research specialisations. Professional, as well as support departments, work systematically on achieving greater success in participation on international projects. Figure 3 shows that the number of implemented international projects more or less copies the funds obtained from these projects. Undoubtedly, for the further development of CxI, it is necessary to focus attention on establishing further international and developing existing collaboration.

The most important international projects implemented at $\mathrm{CxI}$ include:

The project entitled "Innovative Technology based on Constructed Wetlands for the Treatment of Pesticide Contaminated Waters" with the acronym LIFEPOPWAT began in 2020 in the framework of the EU programme LIFE. CxI is the coordinating beneficiary of an international team from four countries. The aim of the project is the full-scale and pilot application of a nature-based remediation system for the treatment of contaminated wastewater containing HCH (lindane) compounds. The technology is called Wetland $+{ }^{\circledR}$.

The project entitled "Integrated Approach to Management of Groundwater Quality In Functional Urban Areas" with the acronym AMIIGA financed from the Interreg Central Europe EU European Regional Development Fund dealt with the management of groundwater contaminated sites in EU countries. CxI's role was mainly to perform biological investigations at contaminated sites. The project was performed between 2016 and 2019.

The large collaborative project entitled "Taking NANOtechnological REMediation Processes from Lab Scale to End User Applications for the Restoration of a Clean Environment" with the acronym NANOREM performed in the framework of EU FP7 dealt with the application of zero-valent nanoparticles for remediation of contaminated groundwater. CxI was the principal investigator of the work package Design, Improvement and Optimised Production of Zero-Valent Iron Nanoparticles. The project was performed between 2013 and 2017. CxI is especially successful in the fields of nanotechnologies, environmental engineering and green chemistry. 


\section{Discussion}

Ways of maintaining and developing international collaboration may be seen in the following steps:

- Support for foreign internships/mobility of employees in research organisations and the private sector, especially long-term stays. Based on previous experience, it is proven that personal networking is more beneficial and sustainable. This makes it easier for $R \& D$ employees to appreciate common $R \& D$ objectives and possible procedures and benefits. An automatic part of every mobility should be the result in the form of a key contact, or other contacts for possible collaboration.

- Planning of networking items with quality execution and organisation. Obtaining contacts usable in the preparation of future and maintenance of existing project activities is the cornerstone for success in the preparation and implementation of international projects.

- Focussing on educating the younger generation, which should be motivated to achieve greater objectives, especially in performing joint international projects that provide wider impacts and benefits. Education of the younger generation also includes the maintenance of quality human capital for the further functioning and development of society. This is also important for the generational change of managers, where the older generation very often focuses on collaboration with local industries and not abroad.

- In relation to the education of the younger generation, the mentor or manager should also focus on the possible shadowing of foreign researchers. $R \& D$ seniors usually have the opportunity to discuss or consult their areas of research with experienced colleagues from abroad. Of course, junior employees should be "shared" for their development, and the development of both institutions.

- In order to stimulate interest, it is also good to host experienced foreign researchers, either for a short-term stay focused mainly on discussions with R\&D employees, or for longer-term mobility enabling joint research and the determination of common R\&D themes in international projects. This measure also includes an increase in the number of researchers from abroad who have been working at the institute for a long time (e.g. foreign $\mathrm{PhD}$ students).

- In order to establish collaboration with foreign workplaces, it is important to obtain an international comparison of ongoing research with leading foreign workplaces. For this, it is important to present the results of research at major international conferences or seminars. During these seminars, it is also possible to learn of advanced themes for further development.

- Support of English leading to the publication of R\&D results in international journals and in collaboration with foreign institutions. Introduction of a fully bilingual environment at $\mathrm{CxI}$.

- Activities leading to joint workplaces with foreign institutions and the ensuing intensive interconnection of research with these institutions.

- In any case, we must not forget motivation, which is the alpha and omega for success in human work. If management does not include participation in international projects among its strategic goals and does not promote this area with various support tools, then there is really very little chance of success of any enthusiastic team for implementation and sustainability in international projects. A specific form of 
motivation may be a financial reward associated with submitting/obtaining an international project. Furthermore, it may be a non-financial reward, for example, in the form of a long-term internship for the establishment of collaboration, or the setting up of a separate $R \& D$ team to implement a specific $R \& D$ plan, etc. It also includes support for the acquisition of unique equipment to perform special research activities.

In order to ensure all of the strategic goals of CxI, the management decided in 2017 to sign up to the European Charter for Researchers and the Code of Conduct for the Recruitment of Researchers. Since the spring of 2020, CxI has been the holder of the HR Award. This award promises to increase the prestige of $\mathrm{CxI}$ at the national, but especially international level. The management of CxI is aware of the importance and positive benefits of involving experienced scientists from abroad; therefore, it is also looking for new scientists in research teams outside the Czech Republic. In addition, this award, and especially the implementation and adherence to the principles of the Charter and the Code, may motivate foreign scientists to work at or collaborate with $\mathrm{CxI}$ in Liberec. The principles of the Charter and the Code are intended to ensure a "better" environment for domestic and existing R\&D\&I employees of CxI. The working group developed an Action Plan reflecting the identified shortcomings. The set actions should ensure quality and fair conditions for human capital. Furthermore, the position of ombudsman was established at $\mathrm{CxI}$ at the beginning of 2020 to ensure equal conditions.

\section{Conclusion}

As a research institute that is part of the Technical University of Liberec, CxI is fully aware of the current trends. The quality of R\&D\&I depends on the effective collaboration of research institutions, i.e. universities, and the application sphere. This interconnection plays a very important role in the economic growth, competitiveness, support of new discoveries, innovative products and services, efficient human resources and the economic activities of all stakeholders involved. Our experience with university-industry collaborative actions is connected to Institute for Nanomaterials, Advanced Technologies and Innovation of TUL.

Due to its focus, CxI mainly implements projects in collaboration with the application sphere, the results of which have a high potential for application on the market. The main providers of national projects that have a dominant representation in the funding of CxI are the Ministry of Industry and Trade and the Technology Agency of the Czech Republic. In addition to national projects, $\mathrm{CxI}$ also collaborates on international projects, although to a much lesser extent. In addition to these international projects, some national projects also have an international dimension, or their results target foreign markets. In order to put the results of R\&D\&I into practice, a Centre for the Support of Technology Transfer was also established at TUL, and a Department for the Promotion and Relations with Industry was established directly at CxI. However, CxI should focus significantly more in its strategic goals on internationalisation and its implementation. If CxI wants to continue to be one of the leading R\&D\&I institutes in the Czech Republic, it is necessary to focus on collaboration with international institutions and enterprises. To strengthen this collaboration, several parallel steps have been taken and will be interpreted in the near future. These include support for foreign mobility and internships, networking, targeted education of the young generation towards international activities, shadowing and 
observation of foreign researchers, active presentations at international conferences, support for publishing activities, creation of joint workplaces and motivation of human resources.

\section{Acknowledgements}

This work was supported by the Ministry of Education, Youth and Sports in the Czech Republic within the framework of project "Professional Contact Organisation of the Safety and Risk of Nanomaterials in the Environment" (registration number LTI17014).

\section{References}

[1] Romer PM. Endogenous technical change. J Political Economy. 1990;98:71-102. Available from: https://www.jstor.org/stable/2937632.

[2] Verspagen B. Economic Growth and Technological Change. An Evolutionary Interpretation. ECD Science, Technology and Industry Working Papers, 2001/01, OECD Publishing. DOI: 10.1787/703445834058.

[3] Jones Ch. Growth and ideas. In: Aghion P, Durlauf SN, editors. Handbook of Economic Growth. Amsterdam: North-Holland Publisher; 2005. ISBN: 9780444520418.

[4] Mokyr J. Long-term economic growth and the history of technology. In: Aghion P, Durlauf SN. editors. Handbook of Economic Growth. Amsterdam: North-Holland Publisher; 2005. ISBN: 9780444520418.

[5] Guellec D, Van Pottelsberghe de la Potterie, B. R\&D and productivity growth - a panel data analysis of 16 OECD countries. OECD Economic Studies. 2001;33(33). DOI: 10.1787/652870318341.

[6] Guellec D, Van Pottelsberghe de la Potterie B. The impact of public R\&D expenditure on business R\&D. Economics Innovation New Technologies. 2010;12:225-44. DOI: 10.1080/10438590290004555.

[7] Armstrong M. A Handbook of Human Resource Management Practice (10th ed.). London: Kogan Page; 2006. ISBN: 0749446315.

[8] Pausits A, editor. Human Resource Management in Higher Education - Case Studies and Future Scenarios. Krems: Edition Donau - Universität Krems; 2015. ISBN: 9783902505774.

[9] Park WG. International R\& D spillovers and OECD Economic growth. Economic Inquiry. 1995;33(4):571-91. DOI: 10.1111/j.1465-7295.1995.tb01882.x.

[10] Coe DT, Helpman E. International R\&D spillovers. Europ Economic Rev. 1995;39, 859-87. DOI: 10.1016/0014-2921(94)00100-E.

[11] Coe DT, Helpman E, Hoffmaister AW. International R\&D spillovers and institutions. Europ Economic Rev. 2009;53(7):723-41. DOI: 10.1016/j.euroecorev.2009.02.005.

[12] Laursen K, Salter A. Searching high and low: what types of firms use universities as a source of innovation? Res Policy. 2003;33(8):1201-15. DOI: 10.1016/j.respol.2004.07.004.

[13] Mansfield E, Lee J-Y. The modern university: contributor to industrial innovation and recipient of industrial R\&D support. Res Policy. 1996;25(7):1047-58. DOI: 10.1016/S0048-7333(96)00893-1.

[14] Maietta OW. Determinants of university-firm R\&D collaboration and its impact on innovation: A perspective from a low-tech industry. Res Policy. 2015;44(7):1341-59. DOI: 10.1016/j.respol.2015.03.006.

[15] Etzkowitz H. Innovation in Innovation: The Triple Helix of University-Industry-Government Relations. Social Sci Information. 2003;42(3):293-337. DOI: 10.1177/05390184030423002.

[16] Etzkowitz H. The Triple Helix. University-Industry-Government Innovation in Action. New York: Routledge; 2008. DOI: 10.4324/9780203929605.

[17] Viale R, Etzkowitz H, editors. The Capitalization of Knowledge. A Triple Helix of University-Industry-Government. High Educ. 2010;63:161-3. DOI: 10.1007/s10734-011-9427-x.

[18] Etzkowitz H, Webster A, Gebhart C, Terra BRC. The future of the university and the university of the future: Evolution of ivory tower to entrepreneurial paradigm. Res Policy. 2000;29(2):313-30. DOI: 10.1016/S0048-7333(99)00069-4.

[19] Urbano D, Guerrero M. Entrepreneurial universities. Socioeconomic impacts of academic entrepreneurship in a European region. Economic Development Quart. 2013;27(1):40-55. DOI: 10.1177/0891242412471973.

[20] Allen S, Link A, Rosenbaum D. Entrepreneurship and human capital: Evidence of patenting activity from the academic sector. Entrepreneurship Theory Practice. 2007;31:937-51. DOI: 10.1111/j.1540-6520.2007.00207.x.

[21] LLS Health CDMO. The Patent Process. 2019. Available from: https://lubrizolcdmo.com/technicalbriefs/the-patent-process/. 
[22] Lennard Elc-Vinnova. Innovation and New Technology. What is the Role of Research? Implications for Public Policy, April, 2014. VINNOVA. Swedish Government Agency for Innovation Systems. ISBN: 9789187537165. Available from: http://www.vinnova.se/upload/EpiStorePDF/va_14_05.pdf.

[23] Perkmann M, Walsh K. University-industry relationships and open innovation: towards a research agenda. Int J Manage Rev. 2007;9(4):259-80. DOI: 10.1111/j.1468-2370.2007.00225.x.

[24] Hall BH. University-industry research partnership in the United States. Report of the European University Institute, Dpt of Economics, San Domenico (FI), Italy, 2004. Available from: http://cadmus.eui.eu/bitstream/id/1735/EC/.

[25] Mowery D, Nelson R, Sampat B, Ziedonis A. Ivory Tower and Industrial Innovation. Stanford: Stanford Business School Press; 2005. ISBN: 9780804795296.

[26] Shane S. Encouraging university entrepreneurship? The effect of the Bayh-Dole Act on university patenting in the United States. J Business Venturing. 2004;19(1):127-51. DOI: 10.1016/S0883-9026(02)00114-3.

[27] Santoro MD, Gopalakrishnan S. The institutionalization of knowledge transfer activities within industry-university collaborative ventures. J Eng Technol Manage. 2000;17(3-4):299-319. DOI: 10.1016/S0923-4748(00)00027-8.

[28] Morandi V. The management of industry-university joint research projects: how do partners coordinate and control R\&D activities? J Technol Transfer. 2013;38(2):69-92. DOI: 10.1007/s10961-011-9228-5.

[29] Boons F, Montaivo C, Quist J, Wagner M. Sustainable innovation, business models and economic performance: an overview. J Cleaner Production. 2013;45:1-8. DOI: 10.1016/j.jclepro.2012.08.013.

[30] Anderson N, Potocnik K, Zhou J. Innovation and creativity in organisations: a state of the science review, prospective commentary and guiding framework. J Manage. 2014;40(5):1297-333. DOI: $10.1177 / 0149206314527128$.

[31] Bowen D, Ostroff C. Understanding HRM-Firm performance linkages: the role of the 'strength' of the HRM system. Acad Manage Rev. 2004;29(2):203-21. DOI: 10.5465/AMR.2004.12736076.

[32] Act 262/2006 Coll., the Labour Code - regulates relationships between employers and employees. Available from: https://www.legislationline.org/download/id/6742/file/Czech_Republic_Labour_Code_2006_am2011_ en.pdf.

[33] Act 111/1998 Coll., the Higher Education Act - regulates freedom of research. Available from: https://www.msmt.cz/uploads/odbor_30/TF/Legislativa_a_metodicke_pokyny/Novela_2016/Zakon_ o_vysokych_skolach_AJ.pdf.

[34] European Commission: Ethical Framework of Research - formulated basic ethical principles of behaviour and conduct of researchers, freedom of research and the related responsibilities. DOI: 10.2777/7491.

[35] Act 121/2000 Coll., the Copyright Act - regulates the protection of intellectual property rights. Available from: www.wipo.int > lexdocs > laws.

[36] Act 527/1990 Coll., on inventions and rationalisation proposals - regulates rights and rules relating to the discovery and implementation of inventions and rationalisation proposals. Available from: www.wipo.int > lexdocs > laws.

[37] Act 478/1992 Coll., on utility models. Available from: www.upv.cz > 478_1992_A_CS.

[38] Rector's Directive 1/2018 Ethics Code for Employees and Students - defines freedom of research and ethical dimensions and procedures at TUL. Available from: https://www.tul.cz/en/international-office/importantuniversity-documents-in-english.

[39] Strategic Plan for the Scholarly, Research and other Creative Activities of TUL 2016-2020 (with annual updates) and Strategic Development Plan of TUL for 2020 with a forward view to 2030 - TUL strategic documents specifying research areas, targets, tools and resources. Available from: https://www.tul.cz/en/international-office/important-university-documents-in-english.

[40] Rector's Directive 2/2015 Protection of Intellectual Property at TUL and Commercialisation of Scientific and Research Results - regulates copyright and industrial property rights at TUL. Available from: https://www.tul.cz/en/international-office/important-university-documents-in-english.

[41] TUL Conditions of Employment - regulates individual and flexible working hours, home office scheme and part-time employment, employee care. Available from: https://www.tul.cz/en/international-office/importantuniversity-documents-in-english.

[42] Internal Wage Regulations - define basic wage levels and motivation components of staff remuneration. Available from: https://www.tul.cz/en/international-office/important-university-documents-in-english.

[43] TUL Collective Agreement - defines relationships among trade unions, employer, employees, outlines rights and obligations. Available from: https://www.tul.cz/en/international-office/important-university-documentsin-english. 